\title{
Greenwashing in environmental marketing strategy in the brazilian furniture market
}

\author{
Greenwashing em estratégia de marketing ambiental no mercado \\ moveleiro brasileiro
}

\author{
Márcia Vieira de Alencar Caldas ${ }^{1}$ (D) , Alípio Ramos Veiga-Neto ${ }^{1}$ (), Luciana Gondim de Almeida Guimarães ${ }^{1}$ (D), \\ Ahiram Brunni Cartaxo de Castro $^{2}$ (D), Glauber Ruan Barbosa Pereira ${ }^{3}$ (C) \\ ${ }^{1}$ Programa de Pós-graduação em Administração, Universidade Potiguar (UnP), Natal (RN), Brasil. E-mails: \\ marciacaldasarquiteta@gmail.com; alipio.veiga@gmail.com; lugondim@gmail.com \\ 2Diretoria de Administração, Instituto Federal de Educação, Ciência e Tecnologia do Rio Grande do Norte (IFRN), Natal (RN), \\ Brasil. E-mail: brunnicastro@hotmail.com \\ ${ }^{3}$ Universidade Federal do Amapá (UNIFAP), Amapá (AP), Brasil. E-mail: adm982@gmail.com
}

\begin{abstract}
How to cite: Caldas, M. V. A., Veiga-Neto, A. R., Guimarães, L. G. A., Castro, A. B. C., \& Pereira, G. R. B. (2021) Greenwashing in environmental marketing strategy in the brazilian furniture market. Revista de Economia e Sociologia Rural, 59(3), e225336. https://doi.org/10.1590/1806-9479.2021.225336
\end{abstract}

\begin{abstract}
Environmental marketing tries to develop strategies to strengthen the entrepreneurial image and connect environmental appeal to products and brands. However, the companies' reputation may be undermined if the green message uses false or inaccurate information, making it seem that theory and practice are far apart. As a consequence, the damage can be irreversible from the consumers' viewpoint. This research aimed at raising and analyzing environmental marketing strategies that denote the practice of greenwashing from the point of view of consumers in the national furniture market. To reach the objective suggested, the research took place in two steps. The first step encompassed a qualitative approach, in which data were collected through interviews. The second step used the quantitative approach, a survey-collection method, and the application of questionnaires with consumers. As a result, it was possible to see that the variables concerning environmental marketing that can be perceived as greenwashing are mostly "preference for environmental products", "interest in green information", "brand-associated trust", "green purchase incentive advertisement" and "a green guidebook generates environmental credibility". The results led to the conclusion that consumers are aware of environmental issues and prefer green products, but greenwashing practices undermine the perception of the company's image and its brands.
\end{abstract}

Keywords: environmental marketing, greenwashing, green marketing strategy, furniture market.

Resumo: O marketing ambiental busca desenvolver estratégias para fortalecer a imagem empresarial e vincular o apelo ambiental aos produtos e marcas. Contudo, a reputação das empresas pode ser prejudicada se a mensagem verde usa informações falsas ou imprecisas, deixando transparecer que o discurso e a prática estão distantes. Como consequência, o prejuízo pode ser irreversível na percepção dos consumidores. Esta pesquisa objetivou levantar e analisar estratégias de marketing ambiental que denotam a prática de greenwashing na percepção de consumidores do mercado moveleiro nacional. Para alcançar o objetivo proposto, a pesquisa ocorreu em duas fases: a primeira com abordagem qualitativa, na qual os dados foram coletados em entrevistas. A segunda fase utilizou abordagem quantitativa, método de coleta survey e aplicação de questionários com consumidores. Como resultado, verificou-se que as variáveis de marketing ambiental que podem ser percebidas como greenwashing são, predominantemente: "preferência por produtos ambientais", "interesse pela informação verde", "confiança associada à marca", "divulgação incentivada de compra verde" e "guia verde gera credibilidade ambiental". Os resultados permitiram concluir que os consumidores têm consciência sobre as questões ambientais e preferência por produtos verdes, mas práticas de greenwashing prejudicam a sua percepção da imagem da empresa e de suas marcas.

Palavras-chave: marketing ambiental, greenwashing, estratégia de marketing verde, mercado moveleiro. 


\section{INTRODUCTION}

Environmental marketing tries to promote strategies to develop positive attitudes that strengthen the differentiated image of the company, its products, and services, by providing brands with an environmental appeal (Lopes \& Pacagnan, 2014). To meet the expectations of clients that are favorable to the environment, organizations get together to adopt new strategies that are pushed by more attentive consumers and by legal obligations. Besides consumers, investors also bet on socially responsible organizations (Chen, 2010; Kim \& Lyon, 2015; Budică \& Dumitru-Traistaru, 2015). Therefore, the trend towards sustainable practices rebound off the market that coordinates the development that is more environmentally balanced and has economic methods. In this context, the organizations that are more able to formulate and set strategies to reach the green market will be ahead in the market (Setiadi et al., 2017; Yang et al., 2013).

The participation of Brazil in international meetings and appointments such as the Agenda 21 and the Eco-92, the Johannesburg Conference or Rio+10, the admission of Brazil into the Marrakech Process, and the Rio+20, brought the country into the discussion about the environmental cause and set guidelines for the matter concerning the environment. Laws, policies, and action plans were set, such as the National Policy of Solid Waste, the National Policy of Climate Change, and the Action Plan for Sustainable Production and Consumption (Dias, 2009). Since then, the determination of consumption patterns started to be discussed worldwide, and this includes the organizations' context, for governmental actions bring together new attitudes into the market concerning the taking of decisions, such as green certification, selective collection, the source of raw material, reverse logistics (Temur \& Bolat, 2017), the use of renewable sources, waste reduction, the use of clean energies (Miguel et al., 2012), and forest management (Bonilla-Bedoya et al., 2017), among others.

Concerning consumers' behavior, it is known that building user's education, adding new clients into the ecologically sustainable market segment, and influencing the consumer during the purchase can be a challenge nowadays in complex and dynamic environments, for the behavior of the consumer who is ecologically aware structures new market perspectives. Demographic, technological, and psychographic aspects can also characterize the groups that are interested in the green cause. Social responsibility communication through green marketing must be committed to the assertive display of the actions that are adopted either as sustainable or as sustainable aspirations, for people's concern with the environmental cause lead them to take on an attitude of differentiated consumption, one that is connected to new values and attitudes that show a concern to protect, benefit and minimize the negative impacts over the environment (Silva et al., 2020; Palazzo et al., 2016; Grimmer \& Woolley, 2014).

To Lins \& Silva (2010), the concern of the organizations to convey a social-environmental image that it does not have can purposefully adhere to the "green stroke" or "green make-up" (Barbieri \& Silva, 2011), as it is known in Brazil, and which is characterized for masking up the real attitudes that are adopted concerning sustainability (Marquis et al., 2016). The Brazilian term is more popular in international literature as greenwashing and it was introduced by the United Nations Conference and announced by the environmental institution called TerraChoice, which defined it as the act of deceiving consumers about a company's environmental practices or the environmental benefits of a product or service. The green attitude that is wrongly advertised through inaccurate information may undermine a brand's reputation and its image, and it can be irreversible when consumers are vigilant (De Jong et al., 2018; Majláth, 2017; Budică \& Dumitru-Traistaru, 2015).

This reality is not different in the Brazilian furniture market, despite the nature of the activity and the environmental impact it causes, for companies oftentimes use the green speech and mechanisms, such as green certificates, to develop greenwashing practices. Therefore, the way the characteristics are being advertised and shown to the consumers and how they see the actions practiced by the organizations resulted in guidelines for the development of this article.

From this setting, there was a need to know the perception of furniture consumers concerning the topic under study and to try to answer the following question: which 
environmental marketing variables that are identified by consumers denote the practice of greenwashing as an entrepreneurial strategy in the national furniture market?

This research aimed at raising and analyzing the environmental marketing strategies that denote the practice of greenwashing from the perception of consumers in the national furniture market. From the academic point of view, according to Akturan (2018), studies that address the consumers' perception of environmental marketing strategies and which denote the practice of greenwashing are still limited. Besides, articles that raise variables for the analysis of the phenomenon in the organizations' practices are still under development (Parguel et al., 2015).

The furniture sector was chosen due to its activity nature because the demand for new attitudes upon extracting and processing this sector's raw material hits society and the environment directly. According to the Sectorial Panorama of Wood and Furniture, established in 2009 by the Brazilian Agency of Industrial Development (Suzigan \& Furtado, 2010), the furniture area market has the growth of a national industry with the mastery of micro and small organizations. Besides, it has fractured characteristics with different operation niches, including those turned to the green market. Certification, for example, was a tool developed to lead new behaviors that are related to the adoption of conservation and native forest management methods worldwide. Thus, it ensures protection acts that guide the consumers' choices since it shows value-added items, which can make a difference, such as energy efficiency and the use of recycled materials, among others (Barbieri \& Silva, 2011).

\section{SOCIAL-ENVIRONMENTAL RESPONSIBILITY, ENVIRONMENTAL MARKETING, AND GREEWASHING}

Social-environmental responsibility incorporates entrepreneurial actions aimed to surpass the observation of the current legislation and socially advance through practices that meet the demands and respect the environment (Boff, 2017), building possibilities that are aimed at the market as a strategy. Entrepreneurial investment in social responsibility actions, including those that are multimodal (seals, certifications, accrediting institutions, and social media, among others), may emphasize a positive image by meeting marketing aspects. In this context, environmental marketing aims at launching into the market products and services that have an environmental appeal, from conception to production, by working out the manufacturers' environmental responsibility (Budică \& Dumitru-Traistaru, 2015).

Some scholars defend that environmental marketing is linked only to the publicity and the promotion of green products (Stall-Meadows \& Davey, 2013). However, the adequate conceptual application lies in the search to meet human needs, having fewer impacts on the environment (Silva et al., 2020; Yang et al., 2013). Yet, the practice of the marketing that adheres to environmental issues brings in advantages by strengthening the relationship between consumers and the organization, and favoring growth and profitability, besides adding an optimistic image concerning the brand of the product that adheres to the green cause (Cassilha et al., 2004).

In their studies, Veiga-Neto et al. (2014) reinforce that, from the entrepreneurs' point of view, environmental marketing is relevant as a strategy. Internal environmental issues must be aligned, advertising must value the environmental issue by showing information of the benefits for society, and the participation of the organization in campaigns that are linked to the green cause must reinforce the image and the relationship of the consumer with the brand assertively and with corporate social responsibility (Lee et al., 2018), by avoiding greenwashing practices.

The use of the term "greenwashing" refers to something that gets ecological attributes and uses the image that fits environmental principles when, in fact, it disguises part of the actions by highlighting positive aspects concerning the environment and masking up other aspects that can be harmful (Delmas \& Burbano, 2011; Schmuck et al., 2018). Greenwashing brings in an adequate entrepreneurial image into the environmental speech. However, it hides steps and processes or minimally contributes to the environment as it values punctual attitudes on behalf of the image that is environmentally adequate (Barbieri \& Silva, 2011).

The United Nations Conference introduced the term greenwashing in 1992. From then on, there has been some direction of actions in several countries in the sense of checking and fighting 
off fake appealing advertisement and the use of environmental marketing with deceitful practices. Organizations such as Greenpeace, the Federal Trade Commission, English agency Futerra, and American consultancy company TerraChoice design guidebooks, handbooks, and guidelines turned to companies to avoid mistakes when advertising their products (Makower, 2012).

According to Ottman (2017) and Laroche et al. (2001), consumers in the entire world already have different opinions upon analyzing green offers to purchase products. Thus, the organizations' good intention to seem appropriate or righteous must show several factors that include the green speech.

From the consumer's point of view, building credibility is the new challenge imposed on environmental marketing management, which demands its operation more completely more and more. The distorted environmental commitment of the real practice adopted can contribute to a broken reputation as it interferes with the organizations' credibility in the market (Rahman et al., 2015; Dahlstrom, 2011).

Authors Diffenderfer \& Baker (2010) confirm the ideas presented and, in their studies, they point out the evidence of greenwashing as "eco-exaggeration" since they argue that the growing labeling of products seen as good for the environment and with few green attributes strengthens the practice to fool consumers. Therefore, the use of green guidebooks may lead organizations that wish to display their environmental attributes in a way that is clear and necessary in order not to create the practice of greenwashing (Diffenderfer \& Baker, 2010).

This way, the image shown by the organizations may be a strategic differential. However, the operation must be legitimate and true (Silva et al., 2020; Barbieri \& Silva, 2011). According to Zhang et al. (2018), companies must promote substantial environmental initiatives instead of greenwashing actions to secure consumers and increase sales.

In this setting, the application of environmental certifications, international entities, regulating systems, and governmental legislation represent the growth of society about environmental issues. That is why a stricter attitude against the use of greenwashing is observed (Yang et al., 2013; Cassilha et al., 2004).

Studies developed by Chen \& Chang (2013), Marquis et al. (2016) and Guo et al. (2017) also identified that consumers are unable to decide about purchasing when companies don't pass on trust in their green actions. The interpretation and the reliability level of information may hamper the understanding and bewilder the perception of green appeal by undermining what will determine the purchase and making organizational actions skeptical. Based on this, the authors developed a theory that determines the perception about greenwashing in two categories: green risk perceived and green trust, which are used when the consumer becomes dependent on the product, service, or a certain brand, and which is the result of the environmental performance associated to the credibility exposed.

Greenwashing was also investigated by Walsh \& Mitchell (2010), who pinpointed six items that show the difficulties to identify greenwashing actions, according to Table 1, below.

Table 1. Difficulties to identify greenwashing actions

Greenwashing practices - difficulties to identify them

(1) product similarity with so-called environmental qualification, which prevents from identifying whether a certain product is greenwashing.

(2) difficulty to identify products based on environmental resources used

(3) excess of environmental characteristics that impair the real identification in the product presented

(4) the growing availability of products offered, which undermines the choice concerning the environment

(5) even after acquiring the product, the consumer rarely finds enough information on the product acquired

(6) insecurity concerning real environmental benefits and characteristics

Source: Adapted from Walsh \& Mitchell (2010).

Previous studies developed by Laufer (2003) had shown that greenwashing is appointed when the company management maximizes environmental actions that are structured to maximize the dissemination of green appeal by omitting noxious attitudes and valuing those 
that have partially green relevance. Table 2 shows the dimensions related to the practices of greenwashing as identified by the author.

Table 2. Dimensions to measure greenwashing actions

\section{Greenwashing dimensions}

(1) if the product discreetly masks up its environmental characteristics

(2) if the product uses graphic and visual aids that fool the consumers concerning its environmental characteristics

(3) if there is a vague and non-verifiable green appeal

(4) if it exaggeratedly emphasizes the green functionality it really has

(5) if the product display omits some information and makes it look greener than it really is Source: Adapted from Laufer (2003).

To Laufer (2003), the dimensions presented can be summarized into three elements that encompass the practice of greenwashing: being something confusing, camouflaging appearance, and adopting a questionable attitude. Greenwashing is, therefore, a shortcut to "misleading manipulation" (Lee et al., 2018; Siano et al., 2017; Seele \& Gatti, 2017). The methodological procedures that enabled this research will be discussed next.

\section{METHODOLOGICAL PROCEDURES}

The research was developed in two steps, one with a basic qualitative approach (Merriam, 1998), with exploratory purposes and with a case-study investigation (Godoy, 1995), and the other one with a quantitative approach (Costa, 2011) and a survey method with a descriptive and cross-section purpose (Freitas et al., 2000).

The research analysis framework was based on literature through studies published by Laufer (2003), Cassilha et al. (2004), Dias (2009), Walsh \& Mitchell (2010), Diffenderfer \& Baker (2010), Dahlstrom (2011), Barbieri \& Silva (2011), Chen \& Chang (2013), Lyon \& Montgomery (2013), De Vries et al. (2015), Rahman et al. (2015), Palazzo et al. (2016), and Boff (2017) and Ottman (2017).

During the qualitative step of the research, we carried out five semi-structured interviews (Gaskell, 2002) from January to February 2015, with managers of furniture micro-enterprises in the city of Natal, Brazil, which were chosen by convenience (Cooper \& Schindler, 2016), to identify variables that complement those of literature, according to Appendix A. The saturation principle was used to limit the number of participants at this stage (Godoi et al., 2006).

Interviews were recorded with the respondents' consent and transcription took place in a second moment. The main points of contribution were recorded through theme analysis (Nowell et al., 2017), described afterward.

The second step of the interview took place through a questionnaire designed from the analysis framework used and the variables raised in the interviews performed. The questionnaire had 30 closed-ended questions that were divided into four blocks, with a Likerttype scale (Costa, 2011) containing five statements ranging from "fully agree" to "fully disagree". We used a non-probabilistic sample and by convenience (Freitas et al., 2000). We used the criterion suggested by Pasquali (1999) that 5 to 10 individuals by item in the tool will be enough for the sample size.

We applied the questionnaire on-line between May and August 2015, with consumers of products from furniture companies identified in social networks. A total of 231 consumers voluntarily participated in the research: 16 from the Southeast region of Brazil, three from the North and Mid-West regions and out of Brazil, two from the South region, and 204 respondents from the Northeast region.

Tables 3 and 4 show the variables related to the greenwashing strategies raised in literature and which composed the research tool. The variables were identified in different tables because they 
were inserted at random into two blocks of statements to keep respondents from jumping to conclusions about one single answer without reading it entirely.

Table 3. Greenwashing variables (strategies) - block 1

\begin{tabular}{|c|c|c|c|}
\hline$\#$ & Variable & Statement & Authors \\
\hline V01 & $\begin{array}{l}\text { Vague label } \\
\text { information }\end{array}$ & $\begin{array}{l}\text { I avoid products whose labels have vague expressions about } \\
\text { environmental practices, such as "friends of nature" or } \\
\text { "ecologically correct". }\end{array}$ & Laufer (2003) \\
\hline V02 & $\begin{array}{l}\text { Green media } \\
\text { appeal }\end{array}$ & $\begin{array}{l}\text { I link an ecological picture to the company when the visual } \\
\text { communication contains images of landscapes or forests. }\end{array}$ & Laufer (2003) \\
\hline V03 & $\begin{array}{l}\text { Belief in green } \\
\text { advertisement }\end{array}$ & $\begin{array}{c}\text { I believe in companies whose ads contain words such as } \\
\text { sustainability, reforestation, recyclable, biodegradable, and } \\
\text { reusable. }\end{array}$ & $\begin{array}{l}\text { Laufer (2003); Boff } \\
\qquad \text { (2017) }\end{array}$ \\
\hline V04 & $\begin{array}{l}\text { Ecological } \\
\text { falsehood }\end{array}$ & $\begin{array}{c}\text { The use of the word sustainability is hollow when the } \\
\text { company hides internal procedures that can jeopardize the } \\
\text { environment. }\end{array}$ & $\begin{array}{l}\text { Boff (2017); Ottman } \\
\text { (2017) }\end{array}$ \\
\hline V05 & $\begin{array}{l}\text { Product's green } \\
\text { certificate }\end{array}$ & $\begin{array}{l}\text { I consider green products those that use green identification } \\
\text { such as "friends of nature" or "ecologically correct". }\end{array}$ & Dahlstrom, (2011) \\
\hline V06 & $\begin{array}{l}\text { Camouflaged } \\
\text { green actions }\end{array}$ & $\begin{array}{l}\text { I don't believe in products that don't display real green } \\
\text { attitudes clearly. }\end{array}$ & $\begin{array}{l}\text { Rahman et al. (2015); } \\
\text { De Vries et al. (2015); } \\
\text { Dahlstrom (2011) }\end{array}$ \\
\hline V07 & $\begin{array}{l}\text { Frailty in green } \\
\text { actions }\end{array}$ & $\begin{array}{c}\text { During the purchase, I can't decide when I believe something } \\
\text { is wrong concerning how green action arguments are } \\
\text { presented. }\end{array}$ & $\begin{array}{l}\text { De Vries et al. (2015); } \\
\text { Chen \& Chang (2013); } \\
\text { Walsh \& Mitchell (2010) }\end{array}$ \\
\hline V10 & $\begin{array}{l}\text { Appealing green } \\
\text { labels }\end{array}$ & $\begin{array}{l}\text { I don't trust the credibility of labels that over-display } \\
\text { something concerning environmental actions. }\end{array}$ & $\begin{array}{l}\text { Diffenderfer \& Baker } \\
\text { (2010) }\end{array}$ \\
\hline
\end{tabular}

Source: Designed by the authors.

Table 4. Greenwashing variables (strategies) - block 2

\begin{tabular}{|c|c|c|c|}
\hline$\#$ & Variable & Statement & Authors \\
\hline V12 & $\begin{array}{l}\text { Partial } \\
\text { environmental } \\
\text { responsibility }\end{array}$ & $\begin{array}{l}\text { Replacing solid wood with replenished MDF panels doesn't } \\
\text { attest to environmental responsibility. }\end{array}$ & Cassilha et al. (2004) \\
\hline V14 & $\begin{array}{l}\text { Partial green } \\
\text { attributes }\end{array}$ & $\begin{array}{l}\text { Advertising the use of reforestation wood, such as Pinewood } \\
\text { or Eucalyptus, in pieces of furniture adds environmental } \\
\text { responsibility to the company. }\end{array}$ & Cassilha et al. (2004) \\
\hline V16 & $\begin{array}{l}\text { Greenwashing } \\
\text { awareness }\end{array}$ & $\begin{array}{l}\text { I am aware of the environmental damage caused by } \\
\text { products that are not totally green. }\end{array}$ & Chen \& Chang (2013) \\
\hline V19 & Lack of evidence & $\begin{array}{l}\text { I get demotivated about purchasing a product when I notice } \\
\text { the lack of ecological action appreciation in furniture } \\
\text { companies. }\end{array}$ & Dias (2009) \\
\hline V20 & $\begin{array}{l}\text { Evidence of the so- } \\
\text { called green brand }\end{array}$ & $\begin{array}{l}\text { I ignore campaigns with an environmental appeal that } \\
\text { advertise the brand with the use of a green speech. }\end{array}$ & Dias (2009) \\
\hline V21 & $\begin{array}{l}\text { Distorted green } \\
\text { speech }\end{array}$ & $\begin{array}{l}\text { I use social networks to report when I acquire products that } \\
\text { don't represent the real green speech. }\end{array}$ & $\begin{array}{l}\text { Lyon \& Montgomery } \\
\qquad(2013,2015)\end{array}$ \\
\hline V22 & $\begin{array}{l}\text { Green camouflage } \\
\text { over } \\
\text { communication }\end{array}$ & $\begin{array}{l}\text { I don't trust in "green camouflage" when companies appeal } \\
\text { to communication to sell the idea of being environmentally } \\
\text { correct. }\end{array}$ & $\begin{array}{l}\text { Palazzo et al. (2016); } \\
\text { Lyon \& Montgomery } \\
\quad(2013,2015)\end{array}$ \\
\hline
\end{tabular}

Source: Designed by the authors.

Tables 5 and 6 , below, show the variables related to environmental marketing that contributed to designing the statements that enabled to complement the contents used in the research tool, which were also raised in the area literature. 
Table 5. Environmental marketing variable - block 3

\begin{tabular}{|c|c|c|c|}
\hline \# & Variable & Statement & Authors \\
\hline V08 & $\begin{array}{l}\text { Interest in green } \\
\text { information }\end{array}$ & $\begin{array}{l}\text { I am interested in the authenticity of sustainable } \\
\text { information }\end{array}$ & Walsh \& Mitchell (2010) \\
\hline V09 & $\begin{array}{l}\text { Preference for } \\
\text { environmental } \\
\quad \text { products }\end{array}$ & $\begin{array}{l}\text { I prefer companies that clearly display their } \\
\text { environmental objectives }\end{array}$ & $\begin{array}{l}\text { Barbieri \& Silva (2011); } \\
\quad \text { Dias (2009) }\end{array}$ \\
\hline V11 & $\begin{array}{c}\text { A green } \\
\text { guidebook } \\
\text { generates } \\
\text { environmental } \\
\text { credibility }\end{array}$ & $\begin{array}{l}\text { I believe in products that clearly display environmental } \\
\text { actions guided by some Green Guidebooks through the } \\
\text { identification of processes }\end{array}$ & $\begin{array}{l}\text { Diffenderfer \& Baker } \\
\qquad(2010)\end{array}$ \\
\hline V13 & $\begin{array}{l}\text { Interest in the } \\
\text { product's origin }\end{array}$ & $\begin{array}{l}\text { I look for information about the "green" source of the raw } \\
\text { material of the furniture pieces I buy }\end{array}$ & Cassilha et al. (2004) \\
\hline V15 & $\begin{array}{l}\text { Clear display of } \\
\text { sustainable } \\
\text { actions }\end{array}$ & $\begin{array}{l}\text { I change my mind and buy from companies that clearly } \\
\text { display their environmental actions }\end{array}$ & Chen \& Chang (2013) \\
\hline
\end{tabular}

Source: Designed by the authors.

Table 6. Environmental marketing variable - block 4

\begin{tabular}{|c|c|c|c|}
\hline$\#$ & Variable & Statement & Authors \\
\hline V17 & $\begin{array}{l}\text { The image of } \\
\text { the consumer is } \\
\text { safeguarded }\end{array}$ & $\begin{array}{l}\text { I refuse to accept products that harm my image of a } \\
\text { mindful consumer }\end{array}$ & $\begin{array}{l}\text { Chen \& Chang } \\
\text { (2013) }\end{array}$ \\
\hline V18 & $\begin{array}{l}\text { Environmental } \\
\text { information } \\
\text { appreciation }\end{array}$ & $\begin{array}{c}\text { I appreciate information available about the } \\
\text { manufacturing process and the environmental } \\
\text { cause adopted by the company during the purchase } \\
\text { of a furniture piece }\end{array}$ & $\begin{array}{l}\text { Ottman (2017); } \\
\text { Parguel et al. } \\
\quad(2015)\end{array}$ \\
\hline V23 & $\begin{array}{l}\text { Interest in } \\
\text { environmental } \\
\text { actions }\end{array}$ & $\begin{array}{c}\text { I follow up on practices of environmental activists in } \\
\text { the search for companies' inadequate } \\
\text { environmental actions }\end{array}$ & $\begin{array}{l}\text { Lyon \& } \\
\text { Montgomery } \\
(2013,2015)\end{array}$ \\
\hline
\end{tabular}

Source: Designed by the authors.

Data processing in the first stage of the research, which was done through a theme analysis, encompassed six processes, according to Nowell et al. (2017): data familiarization, generation of codes, search for topics, review of the topics identified, classification of the topics identified, and report systematization. In these processes, the code frequency count was used as an index for category information coding and highlighting of new variables, which identified four variables about greenwashing and three new variables for the research concerning environmental marketing, as highlighted in Tables 7 and 8, respectively.

Table 7. Greenwashing variable

\begin{tabular}{|c|c|c|}
\hline$\#$ & Variables & Variable Explanation \\
\hline V24 & $\begin{array}{l}\text { Green induction } \\
\text { buying }\end{array}$ & $\begin{array}{l}\text { I am persuaded to buy products when they are linked to other green } \\
\text { products }\end{array}$ \\
\hline V27 & $\begin{array}{l}\text { Environmental cause } \\
\quad \text { engagement }\end{array}$ & $\begin{array}{l}\text { The lack of engagement to environmental causes happens when I do } \\
\text { not understand the process used }\end{array}$ \\
\hline V28 & $\begin{array}{l}\text { Green attitudes in } \\
\text { small actions }\end{array}$ & $\begin{array}{l}\text { I connect small actions, such as recycled paper, to green attitudes in } \\
\text { companies }\end{array}$ \\
\hline V29 & $\begin{array}{l}\text { Green graphic } \\
\text { display as an } \\
\text { attraction }\end{array}$ & $\begin{array}{l}\text { I am attracted by products that display graphic information that } \\
\text { explores landscapes, water, and foliage that resembles the } \\
\text { environment }\end{array}$ \\
\hline
\end{tabular}

Source: Designed by the authors. 
Table 8. Environmental marketing variables

\begin{tabular}{|c|c|c|}
\hline$\#$ & Variables & Variable Explanation \\
\hline V25 & $\begin{array}{l}\text { Green seal as } \\
\text { purchase attraction }\end{array}$ & $\begin{array}{l}\text { Product label display or green seal leads the consumer into } \\
\text { purchasing sustainable products }\end{array}$ \\
\hline V26 & $\begin{array}{l}\text { Brand-associated } \\
\text { trust }\end{array}$ & $\begin{array}{l}\text { I trust the brand when the process used to reach sustainability is } \\
\text { clear }\end{array}$ \\
\hline V30 & $\begin{array}{l}\text { Advertisement } \\
\text { encourages the } \\
\text { mindful purchase }\end{array}$ & Announcing green actions in the media encourages mindful shopping \\
\hline
\end{tabular}

Source: Designed by the authors.

For the second step of the research, data processing was done through electronic spreadsheets, in which data were tabulated, and the standard frequency, mean, and deviation were calculated. In descriptive-quantitative researches, according to Field (2009) and Costa (2011), when a certain variable has a value that is higher than the mean value, its degree of importance is characterized comparing the other variables, for means that are higher than 3 , on a 1-to-5-point scale, showing that there is some agreement as to what will be measured. Moreover, SD is used to show how much the values from which the mean was extracted are either close or distant from the mean itself, that is, to check whether there is inconsistency/mismatch (difference in the replies), for, on a 1-to-5-point scale, when many respondents check the extreme answers, it means the SD will be high. Therefore, values around 1 mean a low SD, the confirmation of means found as positive, and that there is little reply difference.

The research's internal validity and reliability were checked through peer review by four doctor researchers who are specialized in marketing and environmental sustainability. The research's external validity lies in the rich and dense description that tried to understand the perception of a group of individuals in-depth, avoiding ways to generalize the findings for the population (Merriam, 1998). Results and discussions will be presented below.

\section{RESULTS AND DISCUSSION OF THE RESULTS}

This section will show the results and the analyses of the data collected to reply to the objective suggested in the research.

\subsection{Environmental marketing variables}

During the in-depth interview, which is the $1^{\text {st }}$ step of the research, the first statement in the interview asked the interviewees to express their point of view concerning the entrepreneurial strategies used for environmental display and what could either distort or undermine the environmental message. The intention here was to start an open and smooth dialogue so that the responding managers could express their understanding about how environmental marketing has been explored and how the green message is shown.

From the accounts shared, we could see that the interviewees had experiences related to the topic suggested in their own daily life activities. The interviewers pointed out that not every consumer could, actually, use the advertisement adopted by companies due to the lack of awareness concerning the environmental cause. Therefore, for the managers, the use of green advertisement does not influence the consumers' purchasing decision and the lack of consumers' knowledge about the green cause is what maximizes their lack of engagement.

These are unsettling results, for, according to Ottman (2017), appeals concerning the green cause must be encouraged, even if they are individualized. For such, environmental marketing must direct motivational and communicative actions according to the target audience. The green product must establish individual stimuli that are related to time, effort, and money. This way, it will have local consequences and can maximize greater actions and influence others to adhere to the cause. 
The second statement used in the $1^{\text {st }}$ step of the research addressed the environmental certification as a booster and trigger for choosing products to understand the importance attributed to the certifications that concern sales promotion.

As a reply, managers associate positive aspects to the use of green seals and pointed out that, for the consumers who have some knowledge related to the environmental cause, certification is important, for these consumers value the criteria used for certification and, consequently, the choice for certified products will happen for these individuals.

Then, the interviewees were asked how they perceive the exploration of the environmental appeal of the furniture market during the purchase. Through the answers, we observed that advertisement in the furniture sector is still unclear and the use of reforestation boards for manufacturing furniture pieces stands out, the same time it is told whoever demands such proof, for example, the international market. For the respondents, generally speaking, this day-by-day appeal is still not being properly explored.

To Bonilla-Bedoya et al. (2017), this concerns a weak point in the national market, for the international market demands a new posture concerning the use of native wood. Cassilha et al. (2004) also add that other issues are involved in the production process, such as the generation of waste and the use of resources that are still dealt with separately. That is why the adoption of adjusted raw material would be an item in the sustainability process. Environmental responsibility in these steps would mobilize the productive chain as a whole and could strengthen the national market.

Upon considering the variables adopted for the analyses described in the previous section, the $2^{\text {nd }}$ step of the research showed that the highest number of responses is on V9 - Preference for environmental products. The second item mentions the interest in V8, green information (52.4\%). These results mean that the consumers tend to prefer products that have environmental characteristics and that they are interested in the information, as highlighted in Table 9.

Table 9. Higher number of statements concerning fully agree - environmental marketing

\begin{tabular}{|c|c|c|c|c|c|c|c|c|c|c|c|}
\hline \multirow{2}{*}{$\frac{\frac{y}{0}}{\frac{0}{00}}$} & \multirow[t]{2}{*}{ Variables } & \multicolumn{2}{|c|}{ 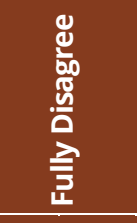 } & \multicolumn{2}{|c|}{ 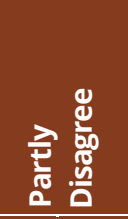 } & \multicolumn{2}{|c|}{ 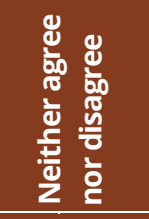 } & \multicolumn{2}{|c|}{ 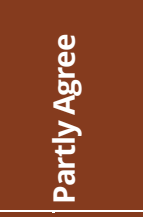 } & \multicolumn{2}{|c|}{ 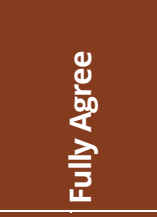 } \\
\hline & & $\mathbf{F}$ & $\%$ & $\mathbf{F}$ & $\%$ & $\mathbf{F}$ & $\%$ & $\mathbf{F}$ & $\%$ & $\mathbf{F}$ & $\%$ \\
\hline V09* & $\begin{array}{l}\text { Preference for environmental } \\
\text { products }\end{array}$ & 8 & 3.5 & 9 & 3.9 & 36 & 15.6 & 57 & 24.7 & 121 & 52.4 \\
\hline V08* & Interest in green information & 6 & 2.6 & 13 & 5.6 & 38 & 16.5 & 53 & 22.9 & 121 & 52.4 \\
\hline V26* & Brand-associated trust & 5 & 2.2 & 5 & 2.2 & 32 & 13.9 & 77 & 33.3 & 112 & 48.5 \\
\hline V30* & $\begin{array}{c}\text { Advertisement encourages mindful } \\
\text { purchase }\end{array}$ & 7 & 3 & 5 & 2.2 & 34 & 14.7 & 77 & 33.3 & 108 & 46.8 \\
\hline $\mathrm{V} 11 *$ & $\begin{array}{l}\text { A green guidebook generates } \\
\text { environmental credibility }\end{array}$ & 3 & 1.3 & 7 & 3 & 36 & 15.6 & 80 & 34.6 & 105 & 45.5 \\
\hline V18* & $\begin{array}{l}\text { Environmental information } \\
\text { appreciation }\end{array}$ & 11 & 4.8 & 15 & 6.5 & 44 & 19 & 69 & 29.9 & 92 & 39.8 \\
\hline V15* & Clear display of sustainable actions & 3 & 1.3 & 10 & 4.3 & 52 & 22.5 & 77 & 33.3 & 89 & 38.5 \\
\hline V25* & Green seal as purchase attraction & 8 & 3.5 & 15 & 6.5 & 45 & 19.5 & 86 & 37.2 & 77 & 33.3 \\
\hline
\end{tabular}

Source: Research data. 
The third variable that stood out was "brand-associated trust" (V26) which, ranging from partly agree (33.3\%) to fully agree (48.5\%), shows the reliability attributed to the brand when the process used by the furniture company to reach sustainability is clear. Thus, the importance of brand association might maximize changes of attitude and reinforce the optimist image for the green path (Guo et al., 2017; Veiga-Neto et al., 2014).

V30 - "advertisement encourages mindful purchase" - comes in fourth place. This way, it confirms the relevance of the work developed by environmental marketing if it is directed to media advertisements concerning green actions. In this context, it confirms studies pinpointed here concerning the role of environmental marketing in the responsibility to advertise positive practices concerning environmental issues, as well as guiding the media in the dissemination of good practices (Dias, 2009).

The use of the green guidebook that mentions sustainable actions and directs environmental practices that are consistent with reality, presented a strong agreement. It confirms the thoughts of Diffenderfer \& Baker (2010), who bring the use of green guidebooks as a reference in the display of environmental attributes by avoiding the practice of greenwashing and building some credibility.

The use of the green seal as an environmental marketing strategy also showed some relative agreement, which indicates the seal's relevance, especially for international demand that requires strict criteria during the production steps (VeigaNeto et al., 2014; Cassilha et al., 2004).

From this perspective, every variable that was analyzed confirms attitudes related to the environmental marketing used as recommended by the authors, which concerns the analysis framework used in this research. The disagreement of these variables would typify the practice of greenwashing.

Table 10 shows that, from the consumers' perception, the veracity of information about environmental cause is still not a full determinant to influence its consumption way. The variables concerning Interest in environmental actions (V23) and Interest in the product's origin (V13), were slightly significant. The results confirm statements from the sector's managers.

Table 10. Higher number of statements concerning fully disagree - environmental marketing

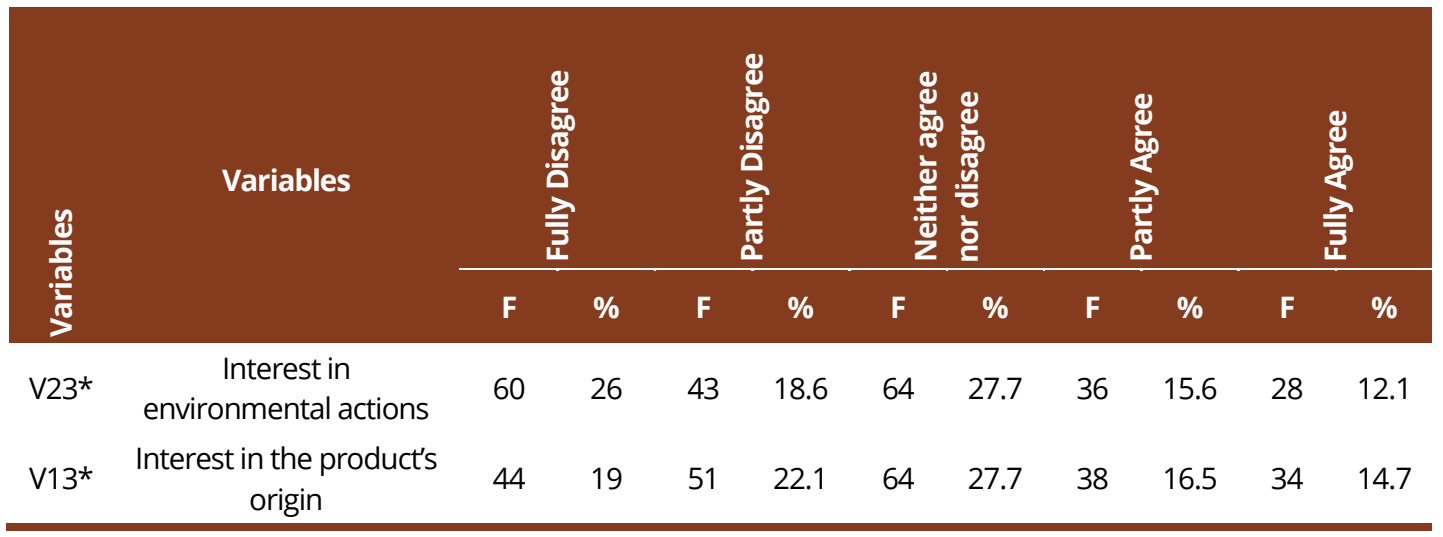

Source: Research data.

Table 11 shows the mean and the standard deviation attributed to each variable in the study and that is related to environmental marketing. In this sense, and by taking into account statements by Field (2009) and Costa (2011), V26 - "associate brand trust with information displayed" was characterized by its level of importance, with a mean of 4.24 and a standard deviation of 0.923 , which means that the respondents' perception confirms the statement from the accounts of the managers interviewed when they said that clear consumer information ends up passing credibility in the processes adopted. 
Table 11. Data: means and standard deviation - environmental marketing variables

$\begin{array}{cccc}\text { Variable name } & \text { N } & \text { Mean } & \text { Standard Deviation } \\ \text { V26 - Brand-associated trust } & 231 & 4.24 & 0.923 \\ \text { V11 - A green guidebook generates environmental credibility } & 231 & 4.20 & 0.901 \\ \text { V09 - Preference for environmental products } & 231 & 4.19 & 1.064 \\ \text { V30 - Advertisement encourages mindful purchase } & 231 & 4.19 & 0.971 \\ \text { V08 - Interest in green information } & 231 & 4.17 & 1.060 \\ \text { V15 - Clear display of sustainable actions } & 231 & 4.03 & 0.950 \\ \text { V18 - Environmental information appreciation } & 231 & 3.95 & 1.116 \\ \text { V25 - Green seal as purchase attraction } & 231 & 3.90 & 1.047 \\ \text { V17 - The image of the consumer is safeguarded } & 231 & 3.33 & 1.222 \\ \text { V13 - Interest in the product's origin } & 231 & 2.86 & 1.313 \\ \text { V23 - Interest in environmental actions } & 231 & 2.69 & 1.334\end{array}$

Source: Research data.

Another relevant meaning is attributed to the variable concerning V11 - "belief in the display of environmental attributes that use a green guidebook". Therefore, the result confirms studies by Diffenderfer \& Baker (2010).

Variable V9, "preference for environmental products", showed a higher response variation. This variable does not express how deep the involvement is. It only informs a trend that should be worked out adequately by marketing to reach better results, both organizational and environmental. Generally speaking, it means that few environmental stimuli encourage the consumer to choose the cause or green products through environmental marketing.

Variable V30 has the same mean as the previous variable, that is, 4.19 . However, it has a lower standard deviation of 0.971 , which confirms the importance of this variable for furniture consumers and was raised in the $1^{\text {st }}$ step of the research. It tried to check the perception that is favorable to "advertisement as a purchase trigger", that is, for the interviewees, media action is positive to encourage mindful shopping, which was confirmed by the respondents. In this context, the benefits and the results that are directed through environmental marketing can maximize choices and promote more involvement of consumers and even employees in companies (Veiga-Neto et al., 2014).

Concerning Variable V8, it had a mean of 4.17 and a standard deviation of 1.060 . The variable concerning "interest for green information" shows a positive index that refers to the information about sustainability. Thus, the veracity of information is a positive point that is attributed to companies. Therefore, fighting off wrongful attitudes in environmental marketing that may cause greenwashing actions by camouflaging actions that are inadequate for the environment undermines the identification by part of the consumers (Walsh \& Mitchell, 2010).

Concerning Variable V15 - "I trust in companies that generate credibility" - the respondents prefer sustainable actions that are displayed clearly. The statement concerning "I change my mind and buy from companies that clearly display their environmental actions" shows the importance of the consumers' perception. Researchers Chen and Chang (2013) pointed out that green appeal is seen with disbelief when it does not transpire credibility. Therefore, the trust would be a premise to capture consumers that are vigilant about the environmental cause (Chen \& Chang, 2013). 
Variable V18, "environmental information appreciation", had a mean of 3.95 and a standard deviation of 1.116. This statement brought in a paradox, for the interviews in the $1^{\text {st }}$ step concluded that environmental information appreciation at the moment of purchasing a piece of furniture was ignored, whereas in the $2^{\text {nd }}$ step there was a meaningful agreement from the consumers. The results show some discrepancy between the managers and the consumers' view, which means that society is more aware of the green cause and that the managers from this sector do not know about consumers' perception. This paradox may influence the strategies and the organizational image directly, for the organization which does not use green marketing as an educational strategy may be losing their room in the market.

Variable V25, which concerns "the use of green seals as a purchase attraction" had a mean of 3.90 and a standard deviation of 1.047. This variable is seen as a differential by the managers who were interviewed in the research, for, through the seal, the company expresses characteristics that belong to the product by informing the actions and meeting the norms and the standards of environmental certification. Therefore, for the company, this information is a sales attraction. This feeling was confirmed by the consumers participating in the research.

\subsection{Environmental marketing variables perceived as greenwashing}

Next, the interviewed professionals (managers) $\left(1^{\text {st }}\right.$ step) were questioned about what could jeopardize the consumers' credibility by describing greenwashing in pro-environmental actions performed in organizations. In this sense, the interviewees associate the organizations' credibility with an ethical attitude and the adoption of certified raw material, confirming statements by Barbieri \& Silva (2011) and Dias (2009). Therefore, variable V13, "Interest in the product's origin", which was a study by Cassilha et al. (2004) about the "green" origin of furniture raw material, may awaken interest in the consumer who is attentive to environmental causes, which strengthens environmental marketing.

The variables highlighted as potential greenwashing practices, which were observed in the $1^{\text {st }}$ step of the research, highlight 4 points of relevance in the use of environmental marketing seen as greenwashing, as shown in Table 8.

Therefore, the data show the points which must be considered by the study area market, presenting new paths and management strategy. Table 12 shows relevant data to be described and analyzed.

Table 12. Number of statements concerning fully agree - Greenwashing

\begin{tabular}{|c|c|c|c|c|c|c|c|c|c|c|c|}
\hline \multirow{2}{*}{$\frac{\frac{y}{0}}{\frac{0}{00}}$} & \multirow[t]{2}{*}{ Variables } & \multicolumn{2}{|c|}{ 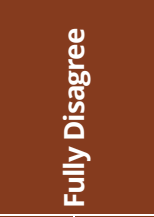 } & \multicolumn{2}{|c|}{ 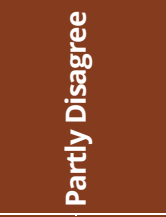 } & \multicolumn{2}{|c|}{ 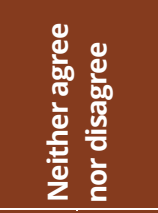 } & \multicolumn{2}{|c|}{ 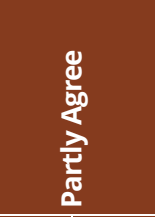 } & \multicolumn{2}{|c|}{ 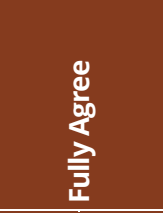 } \\
\hline & & $\mathbf{F}$ & $\%$ & $\mathbf{F}$ & $\%$ & $\mathbf{F}$ & $\%$ & $\mathbf{F}$ & $\%$ & $\mathbf{F}$ & $\%$ \\
\hline V04 & Ecological falsehood & 9 & 3.9 & 11 & 4.8 & 25 & 10.8 & 42 & 18.2 & 144 & 62.3 \\
\hline V16 & $\begin{array}{l}\text { Greenwashing } \\
\text { awareness }\end{array}$ & 5 & 2.2 & 20 & 8.7 & 31 & 13.4 & 60 & 26 & 115 & 49.8 \\
\hline V06 & $\begin{array}{c}\text { Camouflaged green } \\
\text { actions }\end{array}$ & 12 & 5.2 & 26 & 11.3 & 45 & 19.5 & 63 & 27.3 & 85 & 36.8 \\
\hline V12 & $\begin{array}{l}\text { Partial } \\
\text { environmental } \\
\text { responsibility }\end{array}$ & 28 & 12.1 & 13 & 5.6 & 60 & 26 & 47 & 20.3 & 83 & 35.9 \\
\hline V28 & $\begin{array}{l}\text { Green attitudes in } \\
\text { small actions }\end{array}$ & 10 & 4.3 & 17 & 7.4 & 41 & 17.7 & 83 & 35.9 & 80 & 34.6 \\
\hline V03 & $\begin{array}{l}\text { Belief in green } \\
\text { advertisement }\end{array}$ & 8 & 3.5 & 24 & 10.4 & 41 & 17.7 & 87 & 37.7 & 71 & 30.7 \\
\hline
\end{tabular}

Source: Research data. 
The results in Table 12 show that there is an agreement in Variables V4 (Ecological falsehood), V16 (Greenwashing awareness), V6 (Camouflaged green actions), V12 (Partial environmental responsibility), V28 (Green attitude in small actions), and V3 (Belief in the green advertisement). It means that falsely using green attributes interferes with the credibility of the company that intends to show a differential concerning environmental issues (Ottman, 2017). Therefore, using terms that refer to the green cause without showing internal procedures may be characterized as greenwashing, herein identified as the variable that stands out with the highest number in the statement, with $62.3 \%$ of high agreement level. Moreover, each variable shows:

a) V16: greenwashing perception is noticed by the consumers;

b) V06: the identification of greenwashing is attributed to the lack of detailed information; thus, the environmental commitment that is partially shown generates disbelief and may contribute to the lack of credibility since it camouflages actions that could weaken the companies' environmental actions (Dahlstrom, 2011; Rahman et al., 2015; De Vries et al., 2015). V06, or camouflaged green actions, also represents greenwashing actions and $36.8 \%$ of the respondents point out this practice;

c) Variable V12 attributes green characteristics to parts of a piece of furniture. Thus, a step of the process meets the environmental issue. However, this practice cannot be generalized for the entire organization. The attributes must be either partly or totally analyzed and identified according to certification and displayed in an adequate way. The assurance of a product's environmental characteristics is found in its environmental certification. A product's information may ensure an adequate process by building credibility and avoiding generalizations about the product by actually emphasizing the characteristics and processes taken that ensure the responsibility adopted (Barbieri \& Silva, 2011);

d) Variable V28, which was also part of the $1^{\text {st }}$ step, pointed that connecting small actions, such as using recycled paper, to the green attitude in companies may lead to the practice of greenwashing by companies that partly adhere to green and display such action emphatically and are specifically limited to it;

e) Variable V03 explains that the use of expressions that lead to green may enable the practice of greenwashing. Therefore, it is important to understand that the agreement of this variable maximizes consumers to understand that words that suggest sustainability, reforestation, recyclable, biodegradable, and reusable depict green. However, they may not represent the full picture (Walsh \& Mitchell, 2010; Chen \& Chang, 2013).

Table 13 show the variables with a higher number of the statement concerning fully disagree, observing the least relevant variables in the identification of greenwashing.

Table 13. Highest number of statements concerning fully disagree - Greenwashing

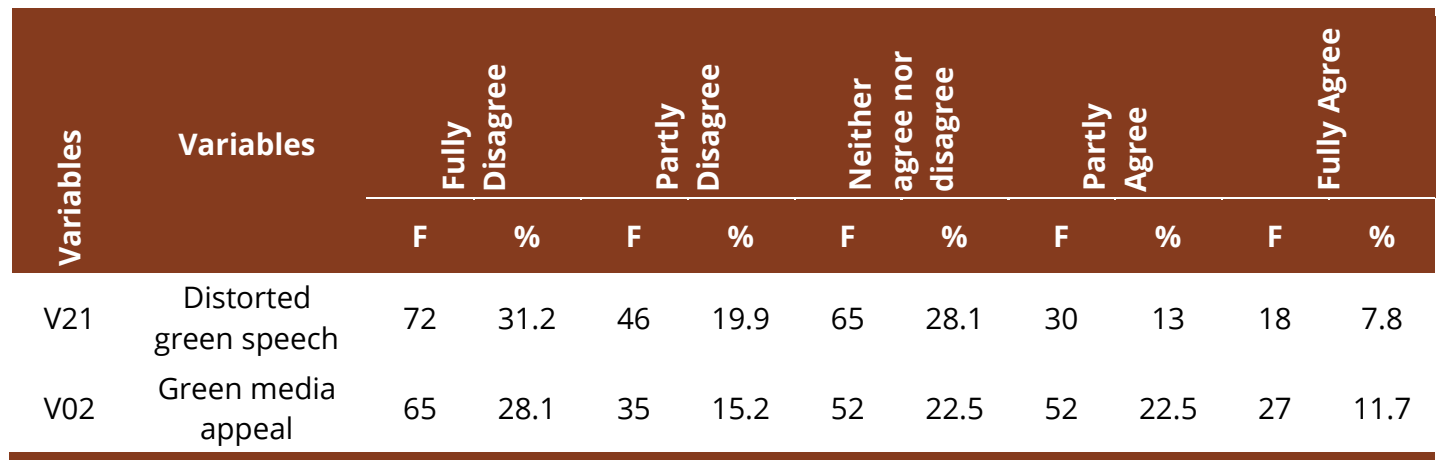

Source: Research data.

Variable V21 showed that consumers do not gather to show and share reports about furniture companies that practice greenwashing actions. In her studies, Ottman (2017) shows that the use of the internet for research and information sharing is growing, not to mention 
the ease of access. Therefore, social media can be a relevant tool to meet an audience that is more demanding and aware of green (Lyon \& Montgomery, 2013).

V02 shows that graphic display with images that resemble nature is not attractive to associate products to the ecological image. Therefore, the investment in green appeals for the visual communication of the product does not necessarily lead to purchasing or adhering to the green cause.

Table 14. Data: means and standard deviation - Greenwashing variables

$\begin{array}{cccc}\text { Variables } & \text { N } & \text { Mean } & \text { Standard Deviation } \\ \text { V04 - Ecological falsehood } & 231 & 4.30 & 1.089 \\ \text { V16 - Greenwashing awareness } & 231 & 4.13 & 1.078 \\ \text { V28 - Green attitudes in small actions } & 231 & 3.89 & 1.096 \\ \text { V03 - Belief in green advertisement } & 231 & 3.82 & 1.088 \\ \text { V06 - Camouflaged green actions } & 231 & 3.79 & 1.201 \\ \text { V27 - Environmental cause engagement } & 231 & 3.63 & 1.095 \\ \text { V12 - Partial environmental responsibility } & 231 & 3.62 & 1.342 \\ \text { V10 - Appealing green label } & 231 & 3.55 & 1.152 \\ \text { V14 - Partial green attributes } & 231 & 3.54 & 1.160 \\ \text { V07 - Frailty in green actions } & 231 & 3.46 & 1.274 \\ \text { V22 - Green camouflage over communication } & 231 & 3.42 & 1.173 \\ \text { V19 - Lack of evidence } & 231 & 3.37 & 1.175 \\ \text { V05 - Product's green certificate } & 231 & 3.29 & .1237 \\ \text { V29 - Green graphic display as an attraction } & 231 & 3.02 & 1.256 \\ \text { V24 - Green induction buying } & 231 & 2.93 & 1.207 \\ \text { V20 - Evidence of the so-called green brand } & 231 & 2.77 & 1.255 \\ \text { V02 - Green media appeal } & 231 & 2.74 & 1.383 \\ \text { V01- Vague label information } & 231 & 2.49 & 1.194 \\ \text { V21- Distorted green speech } & 231 & 2.46 & 1.267\end{array}$

Source: Research data.

Table 14 shows the variables' means and standard deviation. The variable concerning "ecological falsehood" (V04) comes first, with a mean of 4.30 and a standard deviation of 1.08, which shows its importance, according to Field (2009) and Costa (2011), who said that "the use of the word sustainability is hollow when the company hides internal procedures that can jeopardize the environment" is true from the consumers' perception. To Boff (2017), the word sustainability used by some organizations is attributed as ecological falsehood in ads since it uses a green mask to fool consumers and, oftentimes, it can hide issues related to nature aggression.

V16 had a mean of 4.13 and a standard deviation of 1.078 . This variable confirms that the consumers are aware of the harm to the environment that is caused by products that are not totally green. In their studies, Chen \& Chang (2013) show that the negative perception concerning environmental risks interferes in the consumers' behavior and the purchasing decision when they refuse the product or service based on risk identification.

The highest standard deviation (response amplitude) identified in the 30 (thirty) variables researched was variable V02, which concerns green media appeal and had an SD of 1.383 and a mean of 2.74. Based on that, linking promotional material to elements that resemble nature and which could lead to a green choice does not affect the respondents' attention in the research. The statement "I link an ecological picture to the company when the visual communication contains images of landscapes or forests" could show signs of greenwashing practice appealing to shallow environmental attitudes. 
Variables V21 and V01 were selected in this order due to the fact they had a meaningful result, for their lower means represent a disagreement of the statements from the respondents. In these variables, following up on environmental practices, vague label information, and reporting when consumers feel they are being fooled, show that the consumers' behavior upon checking on inadequate actions is still not effective, even if social networks can be accessed by a growing number of people, the respondents do not use them to promote actions and the absence of this attitude in this sense may maximize the practice of greenwashing, even if the organizations do not intend to. The statement in the questionnaire (V01): "I avoid products whose labels have vague expressions about environmental practice, such as "friends of nature" or "ecologically correct" is indifferent to most respondents. The use of these sentences may not call their attention. Thus, avoiding these products because consumers may think the company is greenwashing is still not part of the respondents' attitudes.

\subsection{Greenwashing practices}

The fourth question on the script dealt with green expressions that can weaken the environmental speech. According to the respondents, the consumer may be adhering to the product that carries a green name from the brand without noticing its importance or searching for information about that product. The fact the company presents something related to green or to the indiscriminate use of the green term induces, appeals, and ends up leading the consumer into the green cause without analyzing in detail what it refers to and how it is worked out. This concern is supported by Chen \& Chang (2013).

Generally speaking, consumers may have other demands and needs at the same time they must be active in their environmental participation by valuing pro-environmental actions. Laws and certifications lead to new practices and emphasizing an action based on another may weaken corporate attitudes internally and that may reflect externally, which may undermine organizational credibility (Ottman, 2017).

The sixth statement discussed what impairs the development of pro-environmental actions. According to the interviewees, although they are related to the topic suggested and have executive positions, they agree that there is an educational gap concerning environmental actions that favor the lack of consumers' environmental awareness. Through their replies, the lack of consumers' knowledge was spontaneously identified as the main point. According to these professionals, this undermines their engagement in environmental actions. Thus, the practice of greenwashing as an environmental marketing strategy is not emphasized by the interviewees in the reply analysis, even if the statements pertained to the topic.

It is important to note that environmental marketing must touch the consumers by informing them and leading them to promote choices that are favorable to the environment. Generating positive actions requires work that is specified in this sense. Induction must take place sensibly by encouraging the consumer to promote positive attitudes and which are not induced with the necessary information, and by valuing sustainability and the environmental context.

\section{CONCLUSIONS}

The variables that mostly explained about environmental marketing for the practice of greenwashing were: "preference for environmental products", "interest in green information", "brand-associated trust", "green purchase incentive advertisement", and "a green guidebook generates environmental credibility". In this context, the greenwashing variables that were the most representative for the interviewees were: "ecological falsehood", "greenwashing awareness", "camouflaged green actions", "partial environmental responsibility", "green attitude in small actions", and "belief in the green advertisement".

Through these variables, we could see that the preference for environmental products exists and consumers are aware of greenwashing. However, they do not work actively and 
they do not use tools such as social networks to report or work together with the government and institutions to supervise on behalf of the environment.

The managerial implications of this research show that managers and organizations should know their difficulties to acknowledge greenwashing practices, the dimensions to measure greenwashing, the variables of greenwashing, and of environmental marketing that are involved in the marketing process of their organizations and which are perceived by consumers. From these variables, organizations will be able to develop strategies to strengthen their entrepreneurial image and link the environmental appeal to products and brands assertively.

However, one of the limitations in this research refers to the geographical aspect and to the size of the companies analyzed in the qualitative step undertaken, since the study was restricted to Northeastern Brazil and furniture micro-enterprises. Another limitation was the use of the descriptive and non-inferential quantitative analysis due to multivariate data analysis techniques.

As a suggestion for future studies, the empiric application of the tool used in this research is intended in different contexts, such as covering other regions in the country, other business areas, and other comparative studies that can contribute to the development and growth of the area knowledge and the tool used in the research.

\section{REFERENCES}

Akturan, U. (2018). How does greenwashing affect green branding equity and purchase intention? An empirical research. Marketing Intelligence \& Planning, 36(7), 809-824. http://dx.doi.org/10.1108/MIP12-2017-0339

Barbieri, J. C., \& Silva, D. (2011). Desenvolvimento sustentável e educação ambiental: uma trajetória comum com muitos desafios. RAM. Revista de Administração Mackenzie, 12(3), 51-82.

Boff, L. (2017). Sustentabilidade: o que é-o que não é. Petrópolis: Vozes.

Bonilla-Bedoya, S., Estrella-Bastidas, A., Ordoñez, M., Sánchez, A., \& Herrera, M. A. (2017). Patterns of timber harvesting and its relationship with sustainable forest management in the western Amazon, Ecuador case. Journal of Sustainable Forestry, 36(5), 433-453. http://dx.doi.org/10.1080/10549811.2017.1308869

Budică, I., \& Dumitru-Traistaru, A. (2015). The ascending trend of environmental marketing in the current austerity/crisis period. Polish Journal of Environmental Studies, 24(5), 2301-2304. http://dx.doi.org/10.15244/pjoes/42442

Cassilha, A. C., Podlasek, C. L., Casagrande Junior, E. F., Silva, M. C., \& Mengatto, S. N. F. (2004). Indústria moveleira e resíduos sólidos: considerações para o equilíbrio ambiental. Revista Educação \& Tecnologia, 8, 209-228.

Chen, Y. S. (2010). The drivers of green brand equity: green brand image, green satisfaction, and green trust. Journal of Business Ethics, 93(2), 307-319.

Chen, Y. S., \& Chang, C. H. (2013). Greenwashing and green trust: the mediation of green consumer confusion and green perceived risk. Journal of Business Ethics, 114(3), 489-500.

Cooper, D. R., \& Schindler, P. S. (2016). Métodos de pesquisa em administração. Porto Alegre: McGraw Hill Brasil.

Costa, F. D. (2011). Mensuração e desenvolvimento de escalas: aplicações em administração. Rio de Janeiro: Ciência Moderna.

Dahlstrom, R. (2011). Gerenciamento de marketing verde. São Paulo: Cengage Learning.

De Jong, M. D. T., Harkink, K. M., \& Barth, S. (2018). Making green stuff? Effects of corporate greenwashing on consumers. Journal of Business and Technical Communication, 32(1), 77-112. http://dx.doi.org/10.1177/1050651917729863

De Vries, G., Terwel, B. W., Ellemers, N., \& Daamen, D. D. L. (2015). Sustainability or profitability? How communicated motives for environmental policy affect public perceptions of corporate greenwashing. Corporate Social Responsibility and Environmental Management, 22(3), 142-154.

Delmas, M. A., \& Burbano, V. C. (2011). The drivers of greenwashing. California Management Review, 54(1), 64-87.

Dias, R. (2009). Marketing ambiental: ética, responsabilidade social e competitividade nos negócios. São Paulo: Atlas.. 
Diffenderfer, M., \& Baker, K. C. (2010). Greenwashing: what your client should know to avoid costly litigation and consumer backlash. Natural Resources \& Environment, 25(3), 21-25.

Field, A. (2009). Descobrindo a estatística usando o SPSS. Porto Alegre: Artmed.

Freitas, H., Oliveira, M., Saccol, A. Z., \& Moscarola, J. (2000). O método de pesquisa survey. Revista de Administração da Universidade de São Paulo, 35(3), 105-112.

Gaskell, G. (2002). Entrevistas individuais e grupais. In M. W. Bauer \& G. Gaskell (Eds.), Pesquisa qualitativa com texto, imagem e som: um manual prático. Petrópolis: Vozes.

Godoi, C. K., Bandeira-De-Mello, R., \& Silva, A. D. (2006). Pesquisa qualitativa em estudos organizacionais: paradigmas, estratégias e métodos. São Paulo: Saraiva.

Godoy, A. S. (1995). Introdução à pesquisa qualitativa e suas possibilidades. Revista de Administração de Empresas-RAE, 35(2), 57-63.

Grimmer, M., \& Woolley, M. (2014). Green marketing messages and consumers' purchase intentions: Promoting personal versus environmental benefits. Journal of Marketing Communications, 20(4), 231-250. http://dx.doi.org/10.1080/13527266.2012.684065

Guo, R., Tao, L., Li, C. B., \& Wang, T. (2017). A path analysis of greenwashing in a trust crisis among Chinese energy companies: the role of brand legitimacy and brand loyalty. Journal of Business Ethics, 140(3), 523-536.

Kim, E., \& Lyon, T. P. (2015). Greenwash vs. brownwash: Exaggeration and undue modesty in corporate sustainability disclosure. Organization Science, 26(3), 705-723. http://dx.doi.org/10.1287/orsc.2014.0949

Laroche, M., Bergeron, J., \& Barbaro-Forleo, G. (2001). Targeting consumers who are willing to pay more for environmentally friendly products. Journal of Consumer Marketing, 18(6), 503-520.

Laufer, W. S. (2003). Social accountability and corporate greenwashing. Journal of Business Ethics, 43(3), 253-261.

Lee, H. C. B., Cruz, J. M., \& Shankar, R. (2018). Corporate Social Responsibility (CSR) issues in supply chain competition: should greenwashing be regulated? Decision Sciences, 49(6), 1088-1115. http://dx.doi.org/10.1111/deci.12307

Lins, L. S., \& Silva, R. N. S. (2010). Responsabilidade Sócio-Ambiental ou Greenwash: uma avaliação com base nos relatórios de sustentabilidade ambiental. Sociedade, Contabilidade e Gestão, 4(1), 91-105.

Lopes, V. N., \& Pacagnan, M. N. (2014). Marketing verde e práticas socioambientais nas indústrias do Paraná. Revista ADM, 49(1), 116-128. http://dx.doi.org/10.5700/rausp1135

Lyon, T. P., \& Montgomery, A. W. (2013). Tweetjacked: the impact of social media on corporate greenwash. Journal of Business Ethics, 118(4), 747-757. http://dx.doi.org/10.1007/s10551-013-1958-x

Lyon, T. P., \& Montgomery, A. W. (2015). The means and end of greenwash. Organization \& Environment, 28(2), 223-249. http://dx.doi.org/10.1177/1086026615575332

Majláth, M. (2017). The Effect of Greenwashing Information on Ad Evaluation. European Journal of Sustainable Development, 6(3), 92-104. http://dx.doi.org/10.14207/ejsd.2017.v6n3p92

Makower, J. (2012). Is TerraChoice greenwashing? USA: TerraChoice.

Marquis, C., Toffel, M. W., \& Zhou, Y. (2016). Scrutiny, norms, and selective disclosure: a global study of greenwashing. Organization Science, 27(2), 483-504. http://dx.doi.org/10.1287/orsc.2015.1039

Merriam, S. B. (1998). Case study research in education: a qualitative approach. San Francisco: JosseyBass.

Miguel, G. S., Rincon, S. L., \& Vagiona, D. (2012). Foreward: Clean energy and sustainability: getting ready for the big energy crisis. Global NEST Journal, 14(2), 109-110.

Nowell, L. S., Norris, J. M., White, D. E., \& Moules, N. J. (2017). Thematic analysis: striving to meet the trustworthiness criteria. International Journal of Qualitative Methods, 16(1). http://dx.doi.org/10.1177/1609406917733847

Ottman, J. A. (2017). The new rules of green marketing: strategies, tools, and inspiration for sustainable branding. London: Routledge. http://dx.doi.org/10.4324/9781351278683.

Palazzo, M., Vollero, A., Siano, A., \& Elving, W. J. L. (2016). Avoiding the greenwashing trap: between CSR communication and stakeholder engagement. International Journal of Innovation and Sustainable Development, 10(2), 120-140. http://dx.doi.org/10.1504/IJISD.2016.075542 
Parguel, B., Benoît-Moreau, F., \& Russell, C. A. (2015). Can evoking nature in advertising mislead consumers? The power of 'executional greenwashing'. International Journal of Advertising, 34(1), 107134. http://dx.doi.org/10.1080/02650487.2014.996116

Pasquali, L. (1999). Testes referentes a constructo: teoria e modelo de construção. In L. Pasquali (Org.), Instrumentos psicológicos: manual prático de elaboração (pp. 37-72). Brasília: LabPAM-IBAAP.

Rahman, I., Park, J., \& Chi, C. G. (2015). Consequences of "greenwashing" Consumers' reactions to hotels' green initiatives. International Journal of Contemporary Hospitality Management, 27(6), 10541081. http://dx.doi.org/10.1108/IJCHM-04-2014-0202

Schmuck, D., Matthes, J., \& Naderer, B. (2018). Misleading consumers with green advertising? An affectreason-involvement account of greenwashing effects in environmental advertising. Journal of Advertising, 47(2), 127-145. http://dx.doi.org/10.1080/00913367.2018.1452652

Seele, P., \& Gatti, L. (2017). Greenwashing revisited: in search of a typology and accusation-based definition incorporating legitimacy strategies. Business Strategy and the Environment, 26(2), 239-252. http://dx.doi.org/10.1002/bse.1912

Setiadi, R., Batu, K. L., \& Soesanto, H. (2017). Does an environmental marketing strategy influence marketing and financial performance? A study of Indonesian exporting firms. Market-Tržište, 29(2), 177-192. http://dx.doi.org/10.22598/mt/2017.29.2.177

Siano, A., Vollero, A., Conte, F., \& Amabile, S. (2017). "More than words": expanding the taxonomy of greenwashing after the Volkswagen scandal. Journal of Business Research, 71, 27-37. http://dx.doi.org/10.1016/j.jbusres.2016.11.002

Silva, A. W. P., Coelho, A. L. A. L., Santos, H. C. C., Veiga Neto, A. R., Castro, A. B. C., \& El-Aouar, W. A. (2020). Education principles and practises turned to sustainability in primary school. Environment, Development and Sustainability, 22(7), 6645-6670. http://dx.doi.org/10.1007/s10668-019-00505-2

Stall-Meadows, C., \& Davey, A. (2013). Green marketing of apparel: consumers' price sensitivity to environmental marketing claims. Journal of Global Fashion Marketing, 4(1), 33-43. http://dx.doi.org/10.1080/20932685.2012.753293

Suzigan, W., \& Furtado, J. (2010). Instituições e políticas industriais e tecnológicas: reflexões a partir da experiência brasileira. Estudos Econômicos, 40(1), 7-41. http://dx.doi.org/10.1590/S010141612010000100001

Temur, G. T., \& Bolat, B. (2017). Evaluating efforts to build sustainable WEEE reverse logistics network design: comparison of regulatory and non-regulatory approaches. International Journal of Sustainable Engineering, 10(6), 358-383. http://dx.doi.org/10.1080/19397038.2017.1379572

Veiga-Neto, A. R., Filgueiras, C. R. M., Vasconcelos, C. R. M., \& Almeida, S. T. (2014). Marketing verde aplicado à estratégia como prática: análise de variáveis na visão de empreendedores. Revista Eletrônica do Mestrado Profissional em Administração da Universidade Potiguar, 6(2), 23-37. http://dx.doi.org/10.21714/raunp.v6i2.759

Walsh, G., \& Mitchell, V. (2010). The effect of consumer confusion proneness on word of mouth, trust, and customer satisfaction. European Journal of Marketing, 44(6), 838-859. http://dx.doi.org/10.1108/03090561011032739

Yang, D., Zhao, P., Lou, R., \& Wei, H. (2013). Environmental marketing strategy effects on market-based assets. Total Quality Management \& Business Excellence, 24(5-6), 707-718. http://dx.doi.org/10.1080/14783363.2013.776763

Zhang, L., Li, D., Cao, C., \& Huang, S. (2018). The influence of greenwashing perception on green purchasing intentions: the mediating role of green word-of-mouth and moderating role of green concern. Journal of Cleaner Production, 187, 740-750. http://dx.doi.org/10.1016/j.jclepro.2018.03.201 


\section{APPENDIX A - In-depth interview questions}

1. Which strategies to promote the environmental message do you currently see in the furniture market? What can impair or distort this image?

2. In your opinion, what pushes consumers' credibility away from the pro-environmental actions performed by organizations in the furniture market?

3. Is the use of certification or green seal enough to promote sales? Why?

4. Which "green expressions" may weaken the environmental speech?

5. Do media explore the environmental appeal in the furniture market? How does it work?

6. What impairs the development of pro-environmental actions in the furniture market? 